\title{
Performance of Wheat under Alkali Water and Gypsum Application in Central Plain Zone of Uttar Pradesh, India
}

\author{
Ashwini Singh ${ }^{1 *}$, Raj Kumar ${ }^{2}$, Sandeep Kumar ${ }^{3}$, Brijesh Prajapati ${ }^{2}$ and Ravindra Kumar ${ }^{1}$ \\ ${ }^{1}$ Department of Soil Science and Agricultural Chemistry, Chandra Shekhar Azad University of \\ Agriculture and Technology, Kanpur (U.P.)-208002, India \\ ${ }^{2}$ Department of Soil Conservation and Water Management, Chandra Shekhar Azad University of \\ Agriculture and Technology, Kanpur (U.P.)-208002, India \\ ${ }^{3}$ Department of Agronomy, Chandra Shekhar Azad University of Agriculture and Technology, \\ Kanpur (U.P.)-208002, India \\ *Corresponding author
}

A field experiment was carried out at Crop Research Farm, Nawabganj, C. S. Azad University of Agriculture and Technology, Kanpur during Rabi 2012-13 and 2013-14 in sodic soil with the initial $\mathrm{pH} 9.5, \mathrm{EC} 2.42 \mathrm{dSm}^{-1}$, organic carbon $1.2 \mathrm{~g} \mathrm{~kg}^{-1}$ and

Keywords exchangeable sodium percentage (ESP) 57.10. Tube-well water used for irrigation was alkaline in nature with $\mathrm{pH} 8.2$, electrical conductivity (EC) $1.19 \mathrm{dSm}^{-1}$, sodium absorption

Alkali water, Gypsum bed technology, Nutrient uptake, Residual Sodium Carbonate (RSC), Soil properties.

Article Info

Accepted:

24 February 2017 Available Online: 12 March 2017 ratio (SAR) $10.2 \mathrm{~m} \mathrm{~mol}^{1 / 2} \mathrm{~L}^{-1 / 2}$ and residual sodium carbonate (RSC) $8.8 \mathrm{me} \mathrm{L}^{-1}$. Application of gypsum @ 25\%,50\% and 100\% Gypsum requirement (GR) alone and in combination with alkali water passing through $15 \mathrm{~cm}$ gypsum bed was found significantly superior over control. The maximum grain and straw yield (38.43 and $\left.43.63 \mathrm{q} \mathrm{ha}^{-1}\right)$ was recorded with the application of gypsum @ 50\% GR and alkali water passing through 15 $\mathrm{cm}$ gypsum bed treatment and minimum at control. The changes in $\mathrm{pH}, \mathrm{EC}, \mathrm{SAR}$ and RSC values of alkali irrigation water were from 8.2 to $7.8,1.19$ to $1.47,10.2$ to $4.7 \mathrm{~m} \mathrm{~mol}^{1 / 2} \mathrm{~L}^{-}$ ${ }^{1 / 2}$, and 8.83 to $4.02 \mathrm{me} \mathrm{L}^{-1}$, respectively when the alkali water was passed through $15 \mathrm{~cm}$ gypsum bed. The maximum reduction in $\mathrm{pH}, \mathrm{EC}$ and ESP was recorded 8.0, $1.87 \mathrm{dSm}^{-1}$ and 20.0 , respectively with the application of gypsum $(50 \% \mathrm{GR})+$ gypsum bed $(15 \mathrm{~cm})$ treatment of alkali water. Use of alkali irrigation water (control) considerably raised the value of $\mathrm{pH}, \mathrm{EC}$ and ESP of soil from 9.5 to $10.0,2.42$ to $2.83 \mathrm{dSm}^{-1}$ and 57.10 to 66.15 , respectively from the corresponding initial values, increase in uptake values of $\mathrm{N}, \mathrm{P}, \mathrm{K}$, $\mathrm{Zn}, \mathrm{Ca}$ and $\mathrm{Mg}$ was recorded in all treatment over control, whereas, relatively lower uptake of $\mathrm{Na}$ was recorded in all the treatment in comparison to control.

\section{Introduction}

Wheat (Triticum aestivum L.) is the second most important staple food crop of the world after rice, both in area and production. Wheat is grown in India over an area of about 29.64 million ha with production of 92.46 million tones. Wheat, which is physiologically categorized as a $\mathrm{C}_{3}$ plant, being second most important staple food crop. The major wheat producing states in India are Uttar Pradesh, Punjab, Haryana, Madhya Pradesh etc. These states contribute about $99.5 \%$ of total wheat production in the country. In many arid and 
semi- arid regions, use of saline and sodic water for irrigation in the absence of appropriate soil-water-crop management practices, often leads to the buildup of salinity and sodicity in the soil profile which adversely affect the crop productivity. Each year approximately 10 million hectares (Mha) of the world's irrigated land is abandoned mainly due to secondary salinization and sodication as a consequence of adverse effect of irrigation. In some parts of Rajasthan, Gujarat, Punjab, Haryana, Uttar Pradesh, Andhra Pradesh and Karnataka, the underground water available for irrigation has high sodicity (EC- variable, SAR $>10$ and RSC> 4 me $\mathrm{L}^{-1}$ ). The sodic water containing residual sodium carbonate (RSC) more than $2.5 \mathrm{me} \mathrm{L}^{-1}$ has been considered unsatisfactory for the irrigation (Wilcox et al., 1954). However, Gupta (1983) reported that the irrigation water containing RSC as high as 10 me $\mathrm{L}^{-1}\left(\mathrm{EC}-2 \mathrm{dSm}^{-1}\right.$ and $\left.\mathrm{SAR}<10\right)$ can be applied continually without affecting the yield on loam soils where rainfall is $500-550 \mathrm{~mm}$ during the monsoon season. Application of gypsum 50\% GR and alkali water passing through $15 \mathrm{~cm}$ gypsum bed treatment minimizes the harmful effects of sodic water irrigation on the crop yield and soil properties (Yadav and Chhipa, 2005). Therefore, the present study was undertaken to assess the performance of wheat under alkali water and gypsum application in central plain zone of Uttar Pradesh.

\section{Materials and Methods}

A field experiment was conducted to assess the effect of irrigation water and gypsum on wheat in sodic soil at the Crop Research Farm, Nawabganj of C.S. Azad University of Agriculture and Technology, Kanpur during Rabi seasons of 2012-13 and 2013-14. The soil of the experiment field was loam in texture and sodic in reaction having $\mathrm{pH} 9.5$ and E.C. $2.42 \mathrm{dSm}^{-1}$. The status of organic carbon was $1.2 \mathrm{~g} \mathrm{~kg}^{-1}$ and exchangeable sodium percentage (ESP) was 57.10. There were seven treatments consisted $\mathrm{T}_{1}$ - Control (alkali water), $\mathrm{T}_{2^{-}}$Gypsum bed $(15 \mathrm{~cm})$ treatment (GBT) of alkali water, $\mathrm{T}_{3^{-}}$Soil application (SA) of gypsum (25\% GR), $\mathrm{T}_{4}{ }^{-}$ Soil application of gypsum (25\% GR) + gypsum bed $(15 \mathrm{~cm})$ treatment of alkali water, $\mathrm{T}_{5^{-}}$Soil application of gypsum $(50 \% \mathrm{GR}), \mathrm{T}_{6^{-}}$ Soil application of gypsum (50\% GR) + gypsum bed $(15 \mathrm{~cm})$ treatment of alkali water and $\mathrm{T}_{7}$ - Soil application of gypsum (100\% GR). The experiment was conducted in Randomized Block Design with four replications. $\mathrm{N}, \mathrm{P}_{2} \mathrm{O}_{5}$ and $\mathrm{K}_{2} \mathrm{O}$ were applied @ 120, 60 and $40 \mathrm{~kg} \mathrm{ha}{ }^{-1}$, respectively, through urea, DAP and MOP. Each levels of phosphorus and potassium along with $1 / 3$ dose of urea were added as basal at the time of sowing of wheat crops. Remaining doses of urea $(\mathrm{N})$ was applied at tillering and flowering stage of wheat crops equally. Grain and straw yields were recorded at $14 \%$ moisture content. After harvest of the crop grain and straw sample were collected from each treatment for chemical analysis during each year. Plant and grain sample were powdered and digested in tri acid mixture of concentrated $\mathrm{H}_{2} \mathrm{SO}_{4}$ : $\mathrm{HNO}_{3}: \mathrm{HClO}_{4}(10: 4: 1)$ the concentration of Nitrogen in plant and grain sample were determined by Kjeldahl method (Jackson, 1973). In the extract phosphorus was determined by vanadomolybdate yellow colour method, potassium and sodium by flame photometer and zinc in atomic absorption spectrophotometer (Lindsay and Norvell, 1978), respectively. Treatment wise soil samples were drawn after harvested of wheat during 2013-14 for determination of physical properties of the soil. The gypsum requirement of experimental soil was $5 \mathrm{t} \mathrm{ha}^{-1}$. The depth of gypsum bed was $15 \mathrm{~cm}$ as suggested by Pal and Poonia, 1979. Wheat variety 'KRL-210' was tested with the recommended dose of fertilizers and agronomical practices were adopted as per 
required by crop. Soil application of gypsum was done prior to the last harrowing of the experimental field. The quality of irrigation water was determined by the procedure of (Richards, 1954).

\section{Results and Discussion}

\section{Quality of irrigation water}

The quality of irrigation water markedly improved having passed through $15 \mathrm{~cm}$ gypsum bed (Table-1). Ionic composition of untreated irrigation water were viz. carbonate (Nil), bicarbonate (10.65 me $\left.\mathrm{L}^{-1}\right)$, chloride (0.75 me $\left.\mathrm{L}^{-1}\right)$ and sulphate $\left(0.47 \mathrm{me}^{-1}\right)$, respectively. The content of sodium + potassium and calcium + magnesium in untreated alkali irrigation water was 9.65 me $\mathrm{L}^{-1}$ and $1.82 \mathrm{me} \mathrm{L}^{-1}$, accordingly. Gypsum bed treated alkali irrigation water reduced bicarbonate and sodium ions content by 0.52 and 1.38 me $\mathrm{L}^{-1}$, respectively, with considerable increase in sulphate $\left(3.10\right.$ me $\mathrm{L}^{-}$ ${ }^{1}$ ) and calcium (4.30 me $\left.\mathrm{L}^{-1}\right)$ ions. The values of $\mathrm{pH}, \mathrm{EC}, \mathrm{SAR}$ and RSC values of alkali irrigation water were changed from 8.2 to 7.8 , 1.19 to $1.47 \mathrm{dSm}^{-1}, 10.2$ to $4.7 \mathrm{~m} \mathrm{~mol}^{1 / 2} \mathrm{~L}^{-1 / 2}$, and 8.83 to $4.02 \mathrm{me} \mathrm{L}^{-1}$, respectively, when the alkali water was passed through $15 \mathrm{~cm}$ gypsum bed. The improvement in irrigation water might be due to ameliorative effect of gypsum on anions and cations. These results are in close conformity with the findings of Naga et al., (2015).

\section{Yield and uptake of nutrients}

Data in regard to pooled analysis of grain and straw yield of wheat given in Table-2 showed that the soil application of gypsum $25 \%, 50 \%$ and $100 \%$ GR alone and in combination with alkali water passing through $15 \mathrm{~cm}$ gypsum bed was significantly superior over untreated plot (control). The maximum grain and straw yield (38.43 and $43.63 \mathrm{q} \mathrm{ha}^{-1}$ ) was recorded with the application of gypsum $50 \%$ GR and alkali water passing through $15 \mathrm{~cm}$ gypsum bed treatment followed by soil application of gypsum (100\% GR) and minimum at control. This may be due to that decreasing levels of RSC in irrigation water decreased the ESP and $\mathrm{pH}$ of soil resulting into increased availability of nutrients and decreased the uptake of sodium. These factors to be increased the yield of crop. These results are in agreement with the results of Naga et al., (2015). The other treatments were found statistically at par with each other. Data on uptake of nutrients as a function of biomass yield and nutrient concentration are given in table 2 .

Table.1 Change in $\mathrm{pH}, \mathrm{EC}, \mathrm{SAR}, \mathrm{RSC}$ and ionic composition of alkali water as a result of $15 \mathrm{~cm}$ gypsum bed treatment

\begin{tabular}{|c|c|c|c|c|c|c|c|c|c|c|}
\hline \multirow[t]{2}{*}{ Treatment } & \multirow[t]{2}{*}{ pH } & \multirow{2}{*}{$\begin{array}{c}\mathrm{EC} \\
\left(\mathrm{dSm}^{-1}\right)\end{array}$} & \multicolumn{4}{|c|}{ Anion $\left(\mathrm{me} \mathrm{L}^{-1}\right)$} & \multicolumn{2}{|c|}{ Cation (me $\mathrm{L}^{-1}$ ) } & \multirow[t]{2}{*}{ SAR } & \multirow[t]{2}{*}{ RSC } \\
\hline & & & $\mathrm{CO}_{3}$ & $\mathrm{HCO}_{3}$ & $\mathbf{C l}$ & $\mathrm{SO}_{4}$ & $\mathrm{Ca}+\mathrm{Mg}$ & $\mathbf{N a}+\mathbf{K}$ & & \\
\hline Untreated & 8.2 & 1.19 & Nil & 10.65 & 0.75 & 0.47 & 1.82 & 9.65 & 10.2 & 8.83 \\
\hline Treated & 7.8 & 1.47 & Nil & 10.13 & 0.92 & 3.57 & 6.12 & 8.27 & 4.7 & 4.02 \\
\hline \multicolumn{11}{|l|}{ Change } \\
\hline$(+)$ & - & 0.28 & - & - & 0.17 & 3.10 & 4.30 & - & - & - \\
\hline$(-)$ & 0.41 & - & - & 0.52 & - & - & - & 1.38 & 5.5 & 4.81 \\
\hline
\end{tabular}


Table.2 Effect of alkali water and gypsum on yield and total uptake (Grain + Straw) of wheat (pooled data of two seasons)

\begin{tabular}{|c|c|c|c|c|c|c|c|c|c|}
\hline Treatment & $\begin{array}{c}\text { Grain } \\
\left(\mathbf{q} \mathbf{h a}^{-1}\right)\end{array}$ & $\begin{array}{c}\text { Straw } \\
\left(\mathbf{q} \mathbf{h a}^{-1}\right)\end{array}$ & $\begin{array}{c}\mathrm{N} \\
\left(\mathrm{kg} \mathrm{ha}^{-1}\right)\end{array}$ & $\begin{array}{c}\mathbf{P} \\
\left(\mathrm{kg} \mathrm{ha}^{-1}\right)\end{array}$ & $\begin{array}{c}\mathrm{K} \\
\left(\mathrm{kg} \mathrm{ha}^{-1}\right)\end{array}$ & $\begin{array}{c}\mathrm{Zn} \\
\left(\mathrm{g} \mathrm{ha}^{-1}\right)\end{array}$ & $\begin{array}{c}\text { Ca } \\
\left(\mathrm{kg} \mathrm{ha}^{-1}\right)\end{array}$ & $\begin{array}{c}\text { Mg } \\
\left(\mathrm{kg} \mathrm{ha}^{-1}\right)\end{array}$ & $\begin{array}{c}\mathrm{Na} \\
\left(\mathrm{kg} \mathrm{ha}^{-1}\right)\end{array}$ \\
\hline $\mathrm{T} 1$ & 15.54 & 18.38 & 27.0 & 9.8 & 48.4 & 122.8 & 3.3 & 5.1 & 7.2 \\
\hline $\mathrm{T} 2$ & 23.97 & 27.90 & 38.4 & 14.9 & 60.0 & 141.7 & 5.8 & 8.9 & 5.8 \\
\hline T3 & 21.69 & 25.88 & 34.4 & 12.5 & 54.3 & 134.6 & 6.6 & 8.0 & 7.1 \\
\hline $\mathrm{T} 4$ & 31.50 & 35.57 & 44.7 & 17.2 & 72.1 & 154.9 & 8.7 & 10.3 & 5.4 \\
\hline T5 & 29.79 & 34.86 & 43.4 & 16.6 & 68.9 & 152.5 & 8.3 & 9.2 & 5.1 \\
\hline T6 & 38.43 & 43.63 & 56.8 & 23.4 & 81.9 & 185.9 & 13.3 & 13.7 & 5.0 \\
\hline $\mathrm{T} 7$ & 36.78 & 41.39 & 52.5 & 21.7 & 76.9 & 177.5 & 10.4 & 13.2 & 5.3 \\
\hline $\mathrm{CD}=(0.05)$ & 1.43 & 1.98 & 3.34 & 1.53 & 7.31 & 11.25 & 0.72 & 0.58 & 0.49 \\
\hline
\end{tabular}

Table.3 Change in physical properties of soil as affected by the treatments after harvested of wheat crop during 2013-14

\begin{tabular}{|c|c|c|c|}
\hline Treatment & $\mathbf{p H}$ & $\mathbf{E C}\left(\mathbf{d S m}^{-\mathbf{1}}\right)$ & $\mathbf{E S P}$ \\
\hline Initial & 9.5 & 2.42 & 57.10 \\
\hline T1 & 10.0 & 2.83 & 66.15 \\
\hline T2 & 8.4 & 2.12 & 35.55 \\
\hline T3 & 8.6 & 2.17 & 50.27 \\
\hline T4 & 8.6 & 2.07 & 35.12 \\
\hline T5 & 8.2 & 1.52 & 25.22 \\
\hline T6 & 8.0 & 1.87 & 20.00 \\
\hline T7 & 8.2 & 1.15 & 27.24 \\
\hline
\end{tabular}

Table 2 revealed that the total nitrogen uptake varied from 27 to $56.8 \mathrm{~kg} \mathrm{ha}^{-1}$, phosphorus varied from 9.8 to $23.4 \mathrm{~kg} \mathrm{ha}^{-1}$, potassium ranged from 48.4 to $81.9 \mathrm{~kg} \mathrm{ha}^{-1,}$ zinc uptake varied from 122.8 to $185.9 \mathrm{~g} \mathrm{ha}^{-1}$, calcium from 3.3 to $13.3 \mathrm{~kg} \mathrm{ha}^{-1}$, magnesium varied from 5.1 to $13.7 \mathrm{~kg} \mathrm{ha}^{-1}$ and sodium from 7.2 to $5 \mathrm{~kg} \mathrm{ha}^{-1}$.

There was increase in uptake values of $\mathrm{N}, \mathrm{P}, \mathrm{K}$, $\mathrm{Zn}, \mathrm{Ca}$ and $\mathrm{Mg}$ was recorded in all the treatments over control, whereas, relatively lower uptake of $\mathrm{Na}$ was recorded due to high concentration of exchangeable $\mathrm{Na}^{+}$appeared to increase the adverse effect of sodium on plant growth in sodic soil and decrease in uptake of $\mathrm{Na}$ due to decreasing level of ESP (Jatav et al., 2007).

\section{Soil properties}

Changes in physical properties of soil due to implementation of treatments after harvest of wheat during 2013-14 given in Table-3 revealed that alkali water irrigation considerably raised the value of $\mathrm{pH}, \mathrm{EC}$ and ESP of soil to 10.0, 2.83 $\mathrm{dSm}^{-1}$ and 66.15 , respectively, $\left(\mathrm{T}_{1}\right)$ from the corresponding initial values of 9.5,2.42 $\mathrm{dSm}^{-1}$ and 57.10. A significant reduction in $\mathrm{pH}$ of soil over control was observed due to various combination of soil application of gypsum and passing alkali water through gypsum bed. The maximum reduction in $\mathrm{pH}$ was noticed with the application of gypsum $(50 \% \mathrm{GR})+15 \mathrm{~cm}$ gypsum bed treatment (8.0) followed by soil application of gypsum (100\% GR) alone (8.2). Soil application of gypsum (50\% GR) and $15 \mathrm{~cm}$ gypsum bed treatment of alkali water and remaining combinations were found at par with each other. These findings are related to the finding of (Sharma et al., 2014). There was a slight reduction in the $\mathrm{EC}$ value of soil due to addition 
of gypsum either through soil application or passing alkali water through gypsum bed. The maximum reduction in EC (from 2.42 to 1.15 $\left.\mathrm{dSm}^{-1}\right)$ with the soil application of gypsum $(100 \%$ GR) alone followed by soil application of gypsum (50\% GR) (from 2.42 to $1.52 \mathrm{dSm}^{-1}$ ) and soil application of gypsum (50\% GR) + gypsum bed $(15 \mathrm{~cm})$ treatment of alkali water (from 2.42 to $\left.1.87 \mathrm{dSm}^{-1}\right)$. Application of gypsum through soil application and gypsum bed treatment significantly reduced the ESP of soil over control. Both the levels of gypsum either through soil application or through irrigation water were found statistically at par. Gypsum was found more effective in reclaiming of sodic soil by lowering ESP and increasing exchangeable $\mathrm{Ca}^{2+}$, this was mainly because of that the gypsum is not only supplies $\mathrm{Ca}^{2+}$ but also helps in solubilization of native $\mathrm{CaCO}_{3}$, present in the soil. These findings are in conformity with the findings (Swarup, 1988 and Shishodia et al., 2012).

On the basis of results it is concluded that application of gypsum @ of 50\% GR and alkali water passing through $15 \mathrm{~cm}$ gypsum bed found most effective for minimizing the harmful effect of sodic water irrigation on crop yield and soil properties in central plain zone of Uttar Pradesh.

\section{References}

Gupta, I.C. 1983. Concept of residual sodium carbonate in irrigation water in relation to sodic hazard in irrigated soil. Curr. Agri., 7: 97-103.

Jackson, M.L. 1973. Soil Chemical Analysis. Prentice Hall of India Pvt. Ltd., New Delhi.

Jatav, M.K., Verma, P.K. and Kumar, R.C.M. 2007. Content and total uptake of nutrients ( $\mathrm{Ca}, \mathrm{Mg}, \mathrm{Na}, \mathrm{Zn}$ and $\mathrm{Fe}$ ) in grain and straw of wheat in treated sodic soil as affected by $\mathrm{SAR}, \mathrm{Zn}$ and $\mathrm{Fe}$ application. Int. J. Res. Crops, 8(1): 65-71.

Lindsay, W.L. and Norvell, W.A. 1978.
Development of DTPA soil test for zinc, iron, manganese and copper. Soil Sci. Soc. of America J., 42: 421-428.

Naga, S.R., Yadav, B.L., Sharma, S.R. and Sharma, P. 2015. Effect of RSC of irrigation waters, zinc and iron on yield attributes and yield of wheat grown on typin ustipsamment. Environ. Eco., 33(1B): 568-572.

Pal, R. and Poonia, S.R. 1979. Dimensions of gypsum bed in relation to residual sodium carbonate of irrigation water, sig of gypsum fragments and flow velocity. J. Indian Soc. Soil Sci., 27: 5-10.

Richards, L.A. 1954. Diagnosis and improvement of saline and alkali soils. USDA Handbook No. 60 US Government Printing Office, Washington, D.C., USA.

Sharma, Y., Singh, Y.K., Pareek, N. K. and Verma, B.L. 2014. Use of high RSC water for sustainable crop production under sprinkler irrigation system in Thar desert of Rajasthan. J. Soil water conserve., 13(1): 16-23.

Shishodia, P.K., Dayal, B. and Chauhan, R.S. 2012. Performance of pearl millet- wheat crops irrigated with alkali water with gypsum application. 141. Abstract, $2^{\text {nd }}$ National Seminar on management of Salt Affected Soils and Waters held at CSSRI, RSS Lucknow on 16-17 March, 2012.

Swarup, A. 1988. Influence of organic matter flooding on the chemical and electrochemical properties of sodic soil and rice growth. Plant and Soil, 106: 135-141.

Wilcox, L.V., Blair, G. Y. and Bower, C. A. 1954. Effect of bicarbonate on suitability of water for irrigation. Soil Sci., 77: 259-266.

Yadav, K.K. and Chhipa, B.R. 2005. Effect on organic and inorganic soil amendments on yield and nutrient uptake of wheat irrigated with high RSC water. Ann. Plant and Soil Res., 7(2): 134-138.

\section{How to cite this article:}

Ashwini Singh, Raj Kumar, Sandeep Kumar, Brijesh Prajapati and Ravindra Kumar. 2017. Performance of Wheat under Alkali Water and Gypsum Application in Central Plain Zone of Uttar Pradesh. Int.J.Curr.Microbiol.App.Sci. 6(3): 2300-2304. doi: http://doi.org/10.20546/ijcmas.2017.603.263 